\title{
E-MARKETPLACE BATIK
}

\author{
Berliana Kusuma Riasti \\ Fakultas MIPA, Program Studi D3 Teknik Informatika \\ Universitas Negeri Sebelas Maret \\ Email: berliana.kr@gmail.com \\ Sahirul Alim Tri Bawono \\ Fakultas MIPA, Program Studi D3 Teknik Informatika \\ Universitas Negeri Sebelas Maret \\ Email: sahirul@mipa.uns.ac.id \\ Eksan Setyawan \\ Fakultas MIPA, Program Studi D3 Teknik Informatika \\ Universitas Negeri Sebelas Maret
}

\begin{abstract}
ABSTRAK
Batik adalah warisan budaya dari leluhur bangsa Indonesia. Setiap daerah di Indonesia memiliki motif yang berbeda-beda. Kekhasan batik tersebut menjadi daya tarik bagi semua orang baik dari luar maupun dalam negeri. Tetapi untuk proses promosi yang dilakukan media yang digunakan menggunakan media cetak berupa brosur dan alternatif lain melalui pagelaran pameran batik serta memajangnya di toko-toko.

Website merupakan teknologi yang dapat diakses dengan cepat. Hanya dengan mengetahui alamat website masyarakat dari negara manapun dapat mengakses informasi yang ada di dalam alamat website tersebut. Sehingga dengan menggunakan teknologi tersebut bisa dijadikan media pemasaran yang mudah diakses. Bahasa pemrograman yang digunakan untuk mengembangkan website tersebut adalah dengan menggunakan PHP yang sering dipakai dan mudah dipelajari. Media penyimpanan (database) untuk website tersebut adalah MySQL yang dapat digunakan secara gratis dan powerfull.

Hasil yang diperoleh dari penelitian adalah desain dan aplikasi E-Marketplace Batik. Aplikasi sudah berjalan dengan baik berdasarkan pengujian dengan menggunakan metode BlackBox.
\end{abstract}

Kata kunci: e-marketplace, sistem informasi, batik..

\begin{abstract}
Batik is the ancestral heritage of Indonesia. Every region in Indonesia has a different motif. The distinctiveness of batik appeal to everyone from both outside and inside the country. But to do the media promotion process used to use print media such as brochures and other alternatives through batik exhibition performances and put them on display in stores.

The website is a technology that can be accessed quickly. Only by knowing the website address people from any country can access the information in the address of the website. Therefore, by using these technologies can be used as a marketing medium that is easily accessible. The programming language used to develop websites using PHP are commonly used and easy to learn. Media storage (database) for the website is MYSQL that can be used free of charge and powerful.

Results obtained from this research is the design and application of E-Marketplace Batik. Applications already well underway based on testing using the BlackBox.
\end{abstract}

Keywords: e-marketplace, information systems, batik. 


\section{PENDAHULUAN}

Batik adalah warisan budaya leluhur bangsa Indonesia. Pada masa kerajaan sudah digunakan sebagai pakaian dari kalangan keraton. Sehingga batik itu sendiri dapat dijadikan sebagai identitas Bangsa Indonesia. Selain itu setiap daerah di Indonesia memiliki motif yang berbeda-beda.

Kekhasan batik dapat dijadikan komoditi untuk diperjual belikan. Contoh produk batik tersebut adalah pakaian. Pakaian batik tersebut dapat kita perjual belikan secara luas karena manusia saat ini membutuhkan pakaian tidak hanya sekedar untuk sebagai penutup tubuh saja tetapi juga sebagai penghias diri.

Peluang penjualan pakaian batik itulah yang telah dimanfaatkan oleh para pengusaha konfeksi. Mereka membuat toko-toko yang terdapat pakaian-pakaian batik buatannya dan pada kesempatan tertentu mereka mengikuti pameran-pameran pada tingkat nasional maupun international sebagai media promosi untuk meningkatkan penjualan.

Internet sebagai mendia penyampai informasi dapat digunakan menjadi media pemasaran. Hanya dengan mengetahui alamat website yang dituju maka informasi tersebut dapat diakses dengan mudah walaupun jarak sumber informasi dengan pencari informasi sangatlah jauh. Hal tersebut dapat mengurangi biaya pemasarna terutama di sektor transportasi.

Beberapa penelitian telah dilakukan untuk mengerahui seberapa besar keuntungan penerapan internet untuk media pemasaran. Seperti yang dilakukan oleh Bianchi, C dan Mathews,S. meneliti dampak performa ekspor perusahaan dari pasar negara berkembang. Data yang digunakan adalah 204 perusahaan ekspor di Negara Chile. Hasilnya adalah dampak positif dari penggunaan internet untuk pemasaran yaitu berkembangnya hubungan jaringan bisnis dan bertumbuhnya pasar ekspor [1].

Penelitian lain oleh K. Youngsun dan C. Shin meneliti klaster pemasaran banyak keterhubungan dan ketidak keterhubungan produk dan jasa yang dijual. Contohnya dari pemain dalam klaster pemasaran adalah Tesco, Sears, Carrefour, Walmart, JCPenny dan Meijer. Karena keunikan karakteristik klaster pemasaran tersebut, penelitian pada klaster pemasaran didefinisikan sangat kurang sehingga pendefinisian isu kluster pemasaran perlu didefinisikan, tujuannya adalah pendefinisian statistik pemasaran dengan menggunakan metode untuk klaster pemasaran dan mengimplementasikan metode untuk portal servis pemasaran di Korea dengan berbasis internet. Metodenya menggunakan semua informasi yang mungkin untuk klaster pemasaran yang datanya tidak terlalu sederhana. Hasil analisis menampilkan bahwa portal internet di Korea dapat terselihat seperti sebuah pemasaran meskipun ranking 3 pemain dalam portal internet di korea, Nate, adalah lebih mirip sebagai penedia jasa, bukan pemain yang masuk dalam persaingan kluster pemasaran yang tepat dengan Naver dan Daum [2].

Penelitian tentang kapabilitas pemasaran melalui internet dan pertumbuhan pemasaran melalui internet oleh M. Shane et al. dengan melibat kan 224 perusahan di Australia. Model yang digunakan adalah Structural Equation Modelling (SEM) yaitu mode konseptual dari kapabilitas Internet Marketing dan pertumbuhan pasar internasional. Hasil Penelitian mengindikasikan bahwa perusahaan yang mengembangkan Internet Marketing akan memperoleh keuntungan disebabkan oleh berkurangnya informasi yang tidak pasti dan bertambahnya kemampuan untuk mengembangkan jaringan internasional [3].

Interaksi sosial, akses internet dan pastisipasi pasar saham adalah judul penelitian oleh L. Pinghan dan G. Shinqi meneliti 8000 rumah tangga di China. Mereka mendemonstrasikan interaksi sosial positif berdampak pada pasar saham, tetapi akses internet mengurangi pengaruh interaksi sosial. Khususnya diantara rumah tangga dengan mengakses internet, kemampuan sosial rumah tangga memiliki dampak jika dihubungkan dengan berkurangnya 6 persen poin dalam portabilitas untuk partisipansi terhadap pasar saham. Disini ditemukan pengganti diantara akses internet dan interaksi sosial sebagai sumber informasi. Terlebih lagi identifikasi dampak yang banyak dari interaksi sosial: kehidupan sosialisasi dalam rumah tangga dalam komunitas dengan rata-rata tingginya partisipasi pasar saham lebih seperti untuk berinvestasi saham [4].

\section{UNIFIED MODELING LANGUAGE}

Unified Modeling Language (UML) adalah keluarga notasi grafis yang didukung oleh meta-model tunggal, yang membantu pendeskripsian dan desain sistem perangkat lunak, khususnya sistem yang dibangin menggunakan pemrograman berorientasi objek(OO). Definisi ini merupakan definisi yang sederhana. Pada kenyataannya, pendapat orang-orang tentang UML berbeda satu sama lain.

UML merupakan standar yang relative terbuka yang dikontrol oleh Object Management Group (OMG), sebuah konsorsium terbuka yang terdiri dari banyak perusahaan. OMG dibentuk untuk membuat standar-standar yang mendukung interoperabilitas, khususnya interoperabilitas sistem beroerientasi objek. OMG mungkin lebih 
dikenal dengan standar-standar CORBA (Common Object Request Broker Architecture). UML lahir dari penggabungan banyak bahasa pemodelan grafis berorientasi objek yang berkembang pesat pada akhir 1980-an dan awal 1990-an. Sejak kehadirannya pada tahun 1997, UML menghancurkan Menara Babel tersebut menjadi sejarah [5].

\section{BATIK}

Membatik dapat ditempuh dengan berbagai cara. Berdasarkan cara pembuatannya, batik dapat dibedakan menjadi tiga macam, yaitu (1). Batik tulis : Proses penggambaran lilin batik pada kain menggunakan canting. (2). Batik cap : Proses penggambaran lilin batik pada kain menggunakan cap yang dibentuk sesuai dengan motif yang diinginkan. (3). Batik kombinasi cap tulis : Proses penggambaran malam pada pada kain menggunakan canting dan cap. (4). Batik print : seiring dengan perkembangan teknologi tekstil dan kebutuhan akan adanya produksi massal, saat ini banyak beredar kain bermotif batik atau yang terkenal dengan nama batik print.

Cara pembuatan batik yang paling tradisional dan terkenal di dalam dan luar negeri saat ini adalah Batik Tulis. Motif kain yang dicorak menggunakan canting ini merupakan suatu kegiatan tradisional yang memiliki keunikan tahapan tersendiri mulai dari Mbathik / Nglowong, Nembok, Medel, Ngerok \& Ngirah, Mbironi, Nyoga, Nglorot. Cara tradisional tersebut merupakan cara membatik daerah Solo - Yogyakarta dan sekitarnya berbeda tipis dengan daerah Pekalongan. Batik merupakan kreativitas yang tak pernah selesai dan memiliki latar sejarah panjang di Indonesia. Sebuah sekolah mode tertua asal Roma, Italia, buktinya memasukan desain mode dengan bahan kain batik solo ke dalam kurikulum pelajarannya. Sekolah mode Koefia memandang bahwa batik sebagai warisan budaya dunia yang diakui UNESCO dari Indonesia dapat menjadi tren fashion baru dunia nantinya. Sekolah mode Koefisia akan mengajarkan desain batik solo dan hasilnya akan diikutsertakan dalam berbagai pagelaran fashion week di Italia. Hal ini merupakan kerjasama antara Pemerintah Indonesia dan Italia untuk mengembangkan kebudayaan Indonesia dan memperkenalkan kepada generasi muda Italia. Selain itu, upaya ini sekaligus untuk menggabungkan budaya Solo dengan budaya Eropa.

Melalui sekolah mode Koefia, batik Solo akan diperkenalkan sebagai salah satu warisan budaya yang diakui oleh UNESCO kepada masyarakat terutama kalangan muda Italia. Sekolah mode ini akan mengajarkan desain fashion batik kepada siswanya selama tiga tahun.

Adapun ragam batik sejak awal kemunculannya di Indonesia telah tumbuh dan berkembang seiring dengan pengaruh zaman dan lingkungan. Batik Indonesia, khususnya di Pulau Jawa dengan sendirinya dapat mengungkapkan berbagai hal, seperti asal, siapa yang mengenakan, kapan dikenakan dan makna dibalik pola dan ragam hiasnya. Beberapa ragam batik meliputi Batik Kraton, Batik Pengaruh, Batik, Batik, Batik Pengaruh India, Batik Rifa'iyah, Batik, Batik, Batik Jawa, Batik Indonesia, Batik Modern.

Sejarah pembatikan di Indonesia berkait erat dengan perkembangan kerajaan Majapahit dan penyebaran ajaran Islam di Tanah Jawa. Dalam beberapa catatan, pengembangan batik banyak dilakukan pada Dani Norma Khamzani / Canopy 3.

Masa-masa kerajaan Mataram, kemudian pada masa kerjaan Solo dan Yogyakarta. Kesenian batik adalah kesenian gambar di atas kain untuk pakaian yang menjadi salah satu kebudayaan keluaga raja-raja Indonesia zaman dulu. Lama-lama kesenian batik ini ditiru oleh rakyat terdekat dan selanjutnya meluas menjadi pekerjaan kaum wanita dalam rumah tangganya untuk mengisi waktu senggang.

Selanjutnya, batik yang tadinya hanya pakaian keluarga kraton, kemudian menjadi pakaian rakyat yang digemari, baik wanita maupun pria. Sedang bahan-bahan pewarna yang dipakai tediri dari tumbuh-tumbuhan asli Indonesia yang dibuat sendiri antara lain dari: pohon mengkudu, tinggi, soga, nila, dan bahan sodanya dibuat dari soda abu, serta garamnya dibuat dari tanah lumpur.

Batik Solo terkenal dengan corak dan pola tradisionalnya batik dalam proses cap maupun dalam batik tulisnya. Bahan-bahan yang dipergunakan untuk pewarnaan masih tetap banyak memakai bahan-bahan dalam negeri seperti soga Jawa yang sudah terkenal sejak dari dahulu. Polanya tetap antara lain terkenal dengan "Sidomukti" dan "Sidoluruh". Ke Timur batik Solo dan Yogyakarta menyempurnakan corak batik yang telah ada di Mojokerto serta Tulung Agung. Selain itu juga menyebar ke Gresik, Surabaya dan Madura. Sedang ke arah Barat batik berkem-bang di Banyumas, Pekalongan, Tegal, Cirebon.

Perkembangan pembatikan di daerah-daerah luar selain dari Yogyakarta dan Solo erat hubungannya dengan perkembangan sejarah kerajaan Yogya dan Solo. Corak batik di daerah baru ini disesuaikan pula dengan keadaan daerah sekitarnya. 
Daerah pembatikan yang terkenal sekarang salah satunya di daerah Kampung laweyan Solo. Desa Laweyan yang terletak di tepi Sungai Laweyan ini, dulunya adalah pusat perdagangan Lawe (bahan baku tenun). Bahan baku kapas dipasok dari daerah Juwiring, Pedan dan Gawok. Proses distribusi barang di Pasar Lawe dilakukan melalui bandar Kabanaran yang tak jauh dari Pasar Lawe. Dulu terdapat banyak Bandar di tepi sungai, seperti Bandar Kabanaran, dan Bandar Laweyan. Melalui Bandar inilah yang menghubungkan Desa Laweyan menuju Sungai Bengawan Solo.

Dari sinilah, batik terhubung dengan daerah pesisir. Kampung Laweyan merupakan kawasan sentra industri batik yang unik, spesifik dan bersejarah. Berdasarkan sejarah yang ditulis oleh R.T. Mlayadipuro desa Laweyan (Kampoeng Laweyan) sudah ada sebelum munculnya kerajaan Pajang. Sejarah Laweyan barulah berarti setelah Kyai Ageng Hanis bermukim di desa Laweyan. Pada tahun 1546 M, tepatnya di sebelah utara pasar Laweyan (sekarang Kampung Lor Pasar Mati) dan membelakangi jalan yang menghubungkan antara Mentaok dengan desa Sala (sekarang jalan Dr. Rajiman). Kyai Ageng Henis adalah putra dari Kyai Ageng Sela yang merupakan keturunan raja Brawijaya V. Kyai Ageng Henis atau Kyai Ageng Laweyan adalah juga "manggala pinatuwaning nagara" Kerajaan Pajang semasa Jaka Tingkir menjadi Adipati Pajang pada tahun 1546 M. Setelah Kyai Ageng Henis meninggal dan dimakamkan di pasarean Laweyan (tempat tetirah Sunan Kalijaga sewaktu berkunjung di desa Laweyan), rumah tempat tinggal Kyai Ageng Henis ditempati oleh cucunya yang bernama Bagus Danang atau Mas Ngabehi Sutowijaya. Sewaktu Pajang di bawah pemerintahan Sultan Hadiwijaya (Jaka Tingkir) pada tahun 1568 M Sutowijoyo lebih dikenal dengan sebutan Raden Ngabehi Loring Pasar (Pasar Laweyan). Kemudian Sutowijaya pindah ke Mataram (Kota Gede) dan menjadi raja pertama Dinasti Mataram Islam dengan sebutan Panembahan Senopati yang kemudian menurunkan raja - raja Mataram. Masih menurut RT. Mlayadipuro Pasar Laweyan dulunya merupakan pasar Dani Norma Khamzani / Canopy 3

Lawe (bahan baku tenun) yang sangat ramai. Bahan baku kapas pada saat itu banyak dihasilkan dari desa Pedan, Juwiring, dan Gawok yang masih termasuk daerah Kerajaan Pajang. Adapun lokasi pasar Laweyan terdapat di desa Laweyan (sekarang terletak diantara kampung Lor Pasar Mati dan Kidul Pasar Mati serta di sebelah timur kampung Setono). Di selatan pasar Laweyan di tepi sungai Kabanaran terdapat

sebuah bandar besar yaitu bandar Kabanaran. Melalui bandar dan sungai Kabanaran tersebut pasar Laweyan terhubung ke bandar besar Nusupan di tepi Sungai Bengawan Solo. Pada jaman sebelum kemerdekaan kampung Laweyan pernah memegang peranan penting dalam kehidupan politik terutama pada masa pertumbuhan pergerakan nasional. Sekitar tahun 1911 Serikat Dagang Islam (SDI) berdiri di kampung Laweyan dengan Kyai Haji Samanhudi sebagai pendirinya. Dalam bidang ekonomi para saudagar batik Laweyan juga merupakan perintis pergerakan koperasi dengan didirikannya "Persatoean Peroesahaan Batik Boemi Putera Soerakarta" pada tahun 1935.

Berdasarkan arti Batik bagi Indonesia, berbagai aneka ragam dan cara membatik, serta lokasi bersejarah untuk mendukung kelestarian batik itu sendiri, Di Kota Solo memerlukan sebuah wadah/tempat dengan konsep melestarikan yang berarti memberikan pembelajaran bagi masyarakat awam dalam \& luar negeri umumnya serta para desainer khususnya tentang cara membatik tradisional / batik tulis solo, menyimpan \& memberitahukan informasi sejarah segala tentang batik, yang kemudian agar merangsang pertumbuhan ekonomi bangsa Indonesia agar makmur \& sejahtera umumnya dan khususnya bagi pengusahan batik. Dari hal tersebut diatas penulis memperoleh judul "Batik Center - Pusat Pelatihan Batik Tulis, Peragaan, dan Penjualan Batik di Kota Solo dengan penekanan desain Arsitektur Vernakular [6].

\section{BLACK BOX TESTING}

Black-box testing disebut juga behacioral testing, berfokus pada kebutuhan fungsional sistem. Blackbox testing digunakan untuk menemukan kategori error sebagai berikut [7]:

1. Ketidak sesuaian atau tidak adanya fungsi tertentu.

2. Kesalahan interface.

3. Kesalahan pada struktur data dan akses eksternal database.

4. Kesahalan pada perilaku dan performa.

5. Kesalahan inisialisasi dan terminasi

Test Black-box juga didesain untuk menjawab pertanyaan [7]:

1. Bagaimana validitas fungsionalitas yang dites?

2. Bagaimana perilaku dan performa yang dites?

3. Apakah klas dari input akan membuat kemungkinan test yang baik?

4. Apakah sistem secara khusus sensitif untuk inputan nilai tertentu? 
5. Bagaimana ruang lingkup data class yang diisolasi?

6. Apakah rata-rata data dan volume data dapat ditoleransi sistem?

7. Apakah efek yang akan muncul pada spesifik kombinasi data yang dimiliki sistem operasi?

\section{METODOLOGI PENELITIAN}

Metodologi penelitian berkaitan dengan alat, bahan dan alur penelitian. Alat penelitian terdiri dari software yang digunakan untuk membuat program. Bahan adalah program dan data analisis yang dibuat berdasarkan analisis yang dilakukan. Alur penelitian menyajikan urutan jalannya penelitian.

\subsection{Alat}

Software yang digunakan untuk membuat program adalah sebagai berikut:

1. Xampp sebagai bundle program yang berisi Apache sebagai webserver, MySQL sebagai Database Manajement System.

2. Notepad ++ adalah program editor untuk membuat program berbasis PHP.

\subsection{Bahan}

Bahan yang digunakan untuk penelitian adalah sebagai berikut:

1. Hasil wawarancara dengan beberapa perusahaan batik.

2. Program yang sudah dibuat berdasarkan analisis.

\subsection{Alur Penelitian}

Tahapan-tahap dalam melakukan penelitian (dapat dilihat pada gambar 1) adalah pertama dengan melakukan analisis dari hasil wawancaran kemudian membuat kebutuhan sistem (system requerement). Tahap kedua adalah membuat desain program dengan menggunakan UML. Tahap ketiga adalah membuat program sesuai dengan desain program. Tahap terakhir adalah pengujian fungsionalitas program dengan metode Black box.

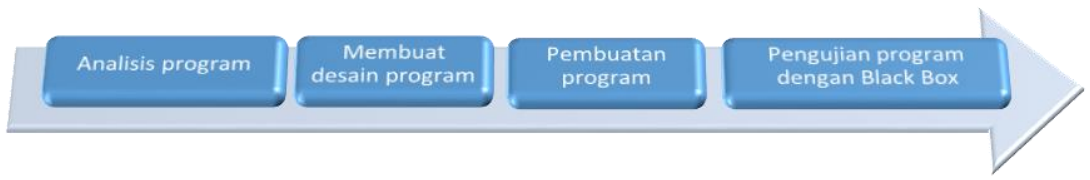

\section{Gambar 1. Alur Penelitian}

\section{HASIL DAN PEMBAHASAN}

Hasil penelitian yang didapat ada beberapa hal yaitu kebutuhan sistem, desain program, hasil pengujian. Kebutuhan sistem berupa tabel kebutuhan sistem hasil analisis (berbentuk kebutuhan fungsional sistem). Desain program menggunakan UML (diagram yang digunakan Use Case dan Class Diagram). Hasil pengujian berupa tabel pengujian fungsionalitas dari form-form yang diperoleh dari analisis kebutuhan sistem.

\subsection{Kebutuhan Sistem}

Kebutuhan sistem yang dibuat adalah kebutuhan fungsional sistem yang dapat dilihat pada Tabel 1 .

Tabel 1. Kebutuhan Fungsional Sistem

\begin{tabular}{|c|c|c|c|}
\hline $\mathrm{NO}$ & DESKRIPSI & AKTOR & DEPEDENSI \\
\hline FR001 & $\begin{array}{l}\text { Sistem mampu menginputkan data } \\
\text { member }\end{array}$ & pengunjung & \\
\hline FR002 & $\begin{array}{l}\text { Sistem mampu menginputkan data } \\
\text { pelapak }\end{array}$ & Pengunjung & \\
\hline FR003 & $\begin{array}{l}\text { Sistem mampu menampilkan data } \\
\text { Produk }\end{array}$ & $\begin{array}{l}\text { Pengunjung, member, } \\
\text { pelapak, agen }\end{array}$ & \\
\hline FR004 & $\begin{array}{l}\text { System mampu menampilkan data } \\
\text { bantuan }\end{array}$ & $\begin{array}{l}\text { Pengunjung, member, } \\
\text { pelapak }\end{array}$ & \\
\hline FR005 & Sistem mampu mencari data produk & $\begin{array}{l}\text { Pengunjung,member , } \\
\text { pelapak, agen }\end{array}$ & \\
\hline FR006 & $\begin{array}{l}\text { Sistem mampu menampilkan Profil } \\
\text { member }\end{array}$ & member & \\
\hline FR007 & $\begin{array}{l}\text { Sistem mampu mengubah Profil } \\
\text { member }\end{array}$ & member & FR006 \\
\hline
\end{tabular}


Indonesian Journal of Applied Informatics, Vol.1 No. 1 November 2016

ISSN: 2548-3846

\begin{tabular}{|c|c|c|c|}
\hline FR008 & $\begin{array}{l}\text { Sistem mampu menampilkan status } \\
\text { transaksi }\end{array}$ & $\begin{array}{l}\text { Member, } \\
\text { pelapak }\end{array}$ & \\
\hline FR009 & $\begin{array}{l}\text { Sistem mampu menampilkan data } \\
\text { pemesanan }\end{array}$ & $\begin{array}{l}\text { Member, } \\
\text { pelapak }\end{array}$ & \\
\hline FR010 & $\begin{array}{l}\text { Sistem mampu menampilkan data } \\
\text { transaksi pembelian }\end{array}$ & $\begin{array}{l}\text { Member, } \\
\text { pelapak }\end{array}$ & \\
\hline FR011 & $\begin{array}{l}\text { Sistem mampu menginputkan data } \\
\text { pemesanan }\end{array}$ & $\begin{array}{l}\text { Member, } \\
\text { pelapak }\end{array}$ & \\
\hline FR012 & $\begin{array}{l}\text { Sistem mampu menginputkan data } \\
\text { konfirmasi pembayaran }\end{array}$ & Member, pelapak & FR009 \\
\hline FR013 & $\begin{array}{l}\text { Sistem mampu menampilkan Profil } \\
\text { pelapak }\end{array}$ & Pelapak & \\
\hline FR014 & $\begin{array}{l}\text { Sistem mampu mengubah Profil } \\
\text { pelapak }\end{array}$ & Pelapak & FR013 \\
\hline FR015 & $\begin{array}{l}\text { Sistem mampu menginputkan data } \\
\text { produk }\end{array}$ & Pelapak & \\
\hline FR016 & Sistem mampu mengubah data produk & Pelapak & FR003 \\
\hline FR017 & Sistem mampu menghapus data produk & $\begin{array}{l}\text { Pelapak } \\
\text { agen }\end{array}$ & FR003 \\
\hline FR018 & $\begin{array}{l}\text { Sistem mampu menampilkan } \\
\text { pemesanan member }\end{array}$ & Pelapak & \\
\hline FR019 & $\begin{array}{l}\text { Sistem mampu menampilkan } \\
\text { penyetoran }\end{array}$ & Pelapak & \\
\hline FR020 & $\begin{array}{l}\text { Sistem mampu menampilkan transaksi } \\
\text { Penjualan }\end{array}$ & Pelapak & \\
\hline FR021 & Sistem mampu meenginputkan konfirmasi engiriman & Pelapak & FR018 \\
\hline FR022 & $\begin{array}{l}\text { Sistem mampu menampilkan notifikasi } \\
\text { transaksi }\end{array}$ & Agen & \\
\hline FR023 & $\begin{array}{l}\text { Sistem mampu menghapus notifikasi } \\
\text { transaksi }\end{array}$ & Agen & FR022 \\
\hline FR024 & $\begin{array}{l}\text { Sistem mampu mengubah status } \\
\text { transaksi }\end{array}$ & Agen & FR022 \\
\hline FR025 & $\begin{array}{l}\text { Sistem mampu menampilkan } \\
\text { konfirmasi pengiriman }\end{array}$ & Agen & \\
\hline FR026 & $\begin{array}{l}\text { Sistem mampu menampilkan } \\
\text { konfirmasi pembayaran }\end{array}$ & Agen & FR025 \\
\hline FR027 & $\begin{array}{l}\text { Sistem mampu menghapus konfirmasi } \\
\text { pengiriman }\end{array}$ & Agen & \\
\hline FR028 & $\begin{array}{l}\text { Sistem mampu menghapus konfirmasi } \\
\text { pembayaran }\end{array}$ & Agen & FR026 \\
\hline FR029 & $\begin{array}{l}\text { Sistem mampu menginputkan data } \\
\text { kategori produk }\end{array}$ & Agen & \\
\hline FR030 & $\begin{array}{l}\text { Sistem mampu menampilkan data } \\
\text { kategori produk }\end{array}$ & Agen & \\
\hline FR031 & $\begin{array}{l}\text { Sistem mampu mengubah data kategori } \\
\text { produk }\end{array}$ & Agen & FR030 \\
\hline FR032 & $\begin{array}{l}\text { Sistem mampu menghapus kategori } \\
\text { produk }\end{array}$ & & FR030 \\
\hline FR033 & $\begin{array}{l}\text { Sistem mampu menginputkan } \\
\text { penyetoran }\end{array}$ & Agen & FR040 \\
\hline FR034 & $\begin{array}{l}\text { Sistem mampu menampilkan data } \\
\text { member }\end{array}$ & Agen & \\
\hline
\end{tabular}




\begin{tabular}{|c|c|c|c|}
\hline FR035 & $\begin{array}{l}\text { Sistem mampu menampilkan data } \\
\text { pelapak }\end{array}$ & Agen & \\
\hline FR036 & Sistem mampu menghapus member & Agen & FR034 \\
\hline FR037 & Sistem mampu menghapus pelapak & Agen & FR035 \\
\hline FR038 & $\begin{array}{l}\text { Sistem mampu menampilkan potongan } \\
\text { Penyetoran }\end{array}$ & Agen & \\
\hline FR039 & $\begin{array}{l}\text { Sistem mampu mengubah data } \\
\text { potongan penyetoran }\end{array}$ & Agen & FR038 \\
\hline FR040 & $\begin{array}{l}\text { Sistem mampu menampilkan data } \\
\text { Transaksi }\end{array}$ & Agen & \\
\hline FR041 & Sistem mampu menghapus transaksi & Agen & FR040 \\
\hline FR042 & Sistem mampu menginputkan data Agen & Agen & \\
\hline FR043 & Sistem mampu menampilkan data agen & Agen & \\
\hline FR044 & Sistem mampu mengubah data agen & Agen & FR043 \\
\hline FR045 & Sistem mampu menghapus agen & Agen & FR043 \\
\hline FR046 & $\begin{array}{l}\text { Sistem mampu menampilkan Tentang } \\
\text { E-Marketplace Batik }\end{array}$ & Pengujung & \\
\hline FR047 & $\begin{array}{l}\text { Sistem mampu menampilkan Aturan } \\
\text { Penggunaan }\end{array}$ & Pengujung & \\
\hline FR048 & $\begin{array}{l}\text { Sistem mampu menampilkan } \\
\text { Pengumuman }\end{array}$ & Pengujung & \\
\hline FR049 & $\begin{array}{l}\text { Sistem mampu menampilkan cara } \\
\text { menjadi member }\end{array}$ & Pengujung & \\
\hline FR050 & $\begin{array}{l}\text { Sistem mampu menampilkan cara } \\
\text { belanja }\end{array}$ & Pengujung & \\
\hline FR051 & $\begin{array}{l}\text { Sistem mampu menampilkan cara } \\
\text { pembayaran }\end{array}$ & Pengujung & \\
\hline FR052 & $\begin{array}{l}\text { Sistem mampu menampilkan peraturan } \\
\text { menjadi member }\end{array}$ & Pengujung & \\
\hline FR053 & $\begin{array}{l}\text { Sistem mampu menampilkan cara } \\
\text { menjadi pelapak }\end{array}$ & Pengujung & \\
\hline FR054 & $\begin{array}{l}\text { Sistem mampu menampilkan cara } \\
\text { berjualan }\end{array}$ & Pengujung & \\
\hline FR055 & $\begin{array}{l}\text { Sistem mampu menampilkan peraturan } \\
\text { menjadi pelapak }\end{array}$ & Pengujung & \\
\hline FR056 & Sistem mampu menampilkan data slide & Pelapak & \\
\hline FR057 & Sistem mampu mengubah data slide & Pelapak & \\
\hline FR058 & $\begin{array}{l}\text { Sistem mampu menginputkan produk yang di tampilkan di } \\
\text { slider }\end{array}$ & Pelapak & \\
\hline FR059 & Sistem mampu mencetak laporan penyetoran & Agen & \\
\hline FR060 & Sistem mampu post ke sosial media & Sistem & \\
\hline
\end{tabular}

\subsection{Use Case}

Use Case berikut menggambarkan para pelaku sistem dengan dengan sistem seperti pada Gambar 2 
Indonesian Journal of Applied Informatics, Vol.1 No. 1 November 2016

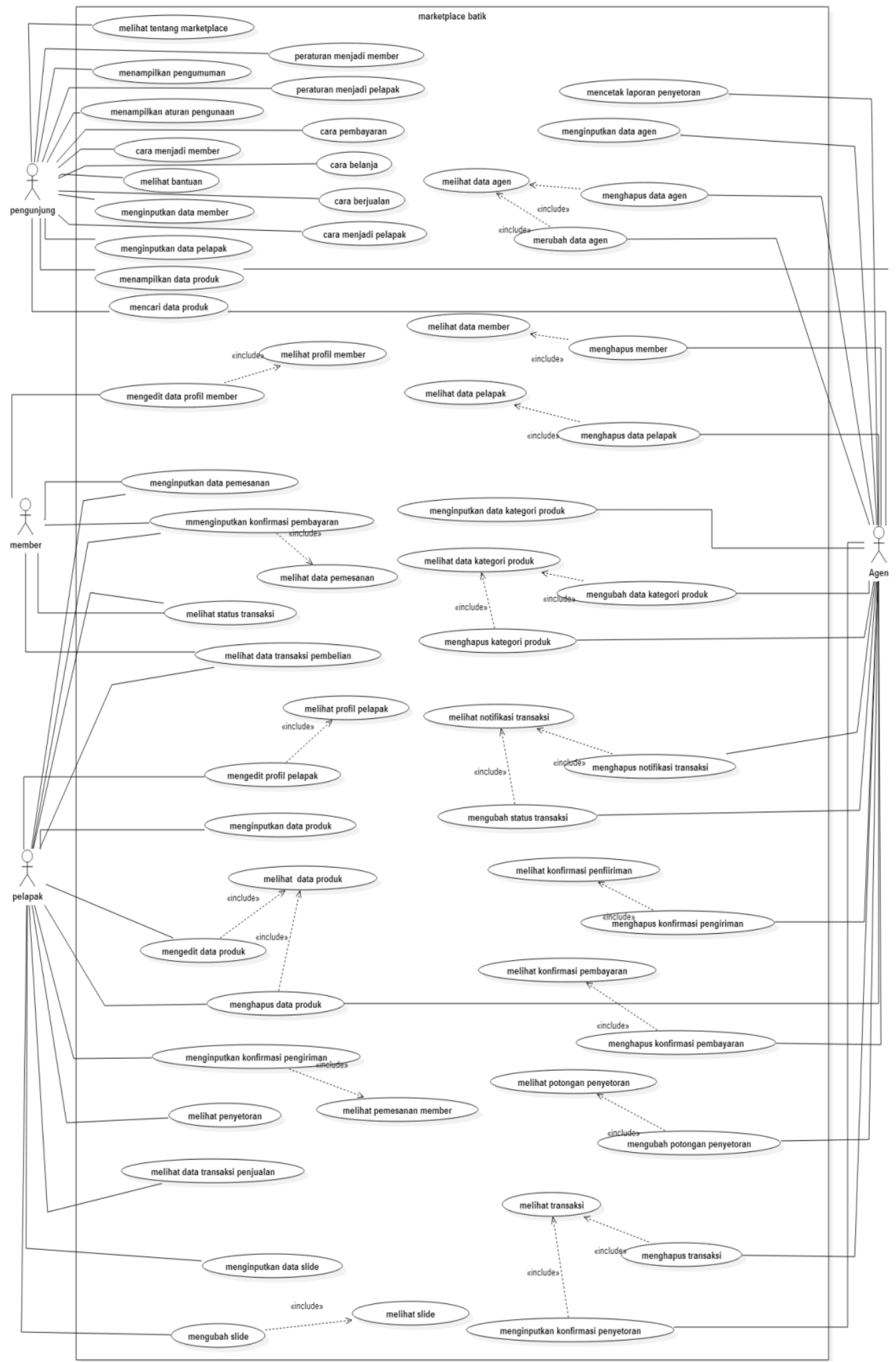

Gambar 2. Use Case 


\subsection{Class Diagram}

Jumlah class diagram yang dimiliki 14 buah yang nantinya akan dibuat secara teknis di pemrogramannya. Class diagram tersebut dapat dilihat pada Gambar 3.

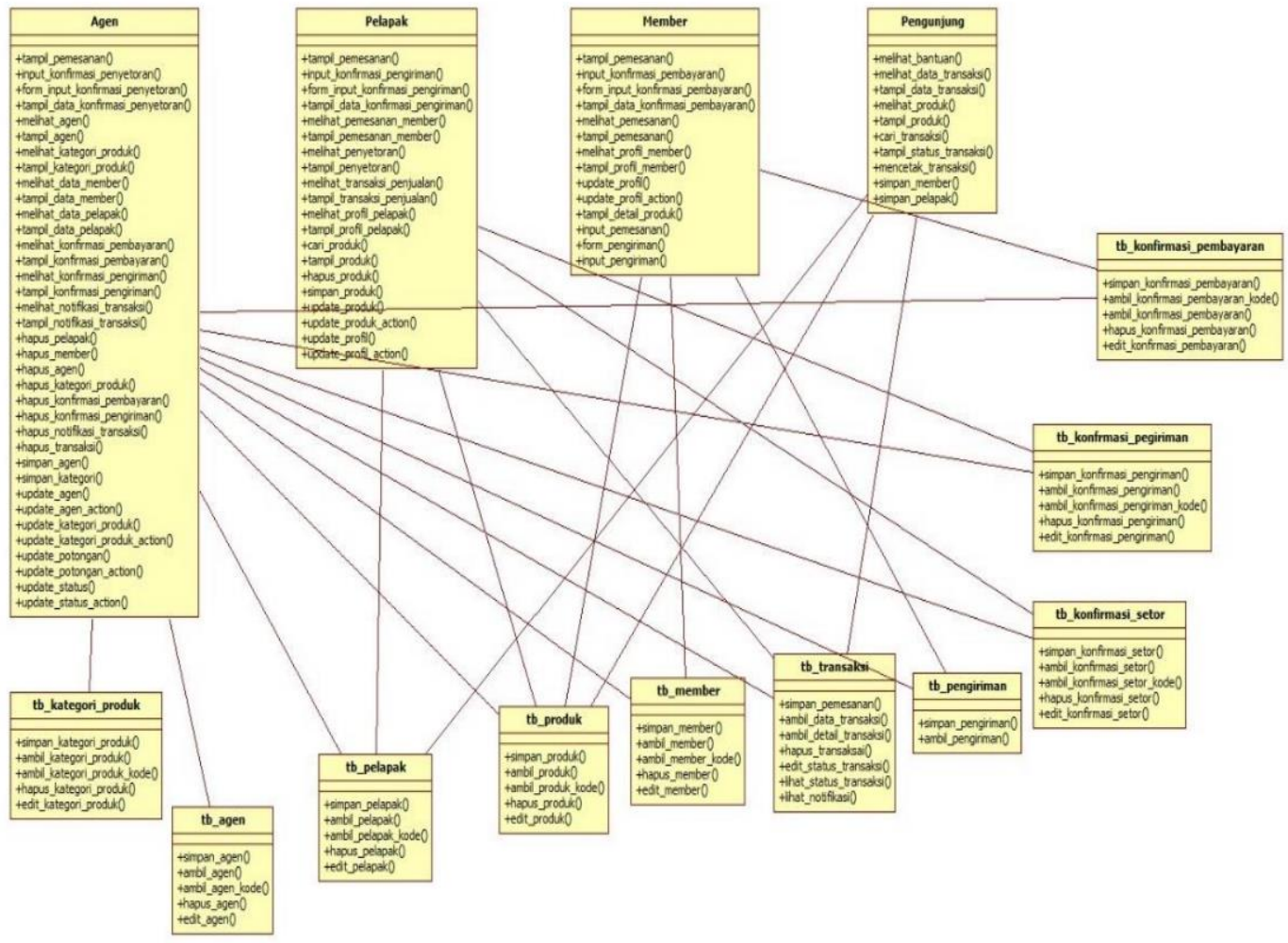

Gambar 3. Class Diagram

\subsection{Hasil pengujian Black Box}

Hasil pengujian dapat dilihat pada Tabel 2. Daftar pengujian berdasarkan kebutuhan fungsional.

Tabel 2. Tabel Pengujian dengan Menggunakan Black-box

\begin{tabular}{|c|c|c|c|c|}
\hline No & $\begin{array}{c}\text { Kasus/Form Yang } \\
\text { Diuji }\end{array}$ & Skenario Sistem & $\begin{array}{c}\text { Hasil Yang } \\
\text { Diharapkan }\end{array}$ & Kesimpulan \\
\hline 1 & $\begin{array}{l}\text { Menginputkan data } \\
\text { member }\end{array}$ & $\begin{array}{l}\text { Pengunjung } \\
\text { menginputkan data diri } \\
\text { untuk menjadi member }\end{array}$ & $\begin{array}{l}\text { Menyimpan data pengunjung } \\
\text { dan pengunjung sudah menjadi } \\
\text { member }\end{array}$ & Berhasil \\
\hline 2 & $\begin{array}{l}\text { Menginputkan data } \\
\text { pelapak }\end{array}$ & $\begin{array}{l}\text { Pengunjung menginputkan } \\
\text { data diri untuk menjadi } \\
\text { pelapak }\end{array}$ & $\begin{array}{l}\text { Menyimpan data pengunjung } \\
\text { dan pengunjung sudah menjadi } \\
\text { pelapak }\end{array}$ & Berhasil \\
\hline 3 & $\begin{array}{l}\text { Menampilkan data } \\
\text { produk }\end{array}$ & $\begin{array}{l}\text { Pengunjung memilih } \\
\text { menampilkan data produk }\end{array}$ & Menampilkan semua produk & Berhasil \\
\hline
\end{tabular}


Indonesian Journal of Applied Informatics, Vol.1 No. 1 November 2016

ISSN: 2548-3846

\begin{tabular}{|c|c|c|c|c|}
\hline 4 & $\begin{array}{l}\text { Menampilkan } \\
\text { bantuan }\end{array}$ & $\begin{array}{l}\text { Pengunjung memilih } \\
\text { menampilkan bantuan }\end{array}$ & Menampilkan bantuan & Berhasil \\
\hline 5 & Mencari data produk & $\begin{array}{l}\text { Pengunjung } \\
\text { mencari produk dengan } \\
\text { memasukkan keyword } \\
\text { tertentu }\end{array}$ & $\begin{array}{l}\text { Menampilkan produk hasil } \\
\text { dari pencarian produk } \\
\text { dengan menggunakan keyword }\end{array}$ & Berhasil \\
\hline 6 & $\begin{array}{l}\text { Menampilkan Profil } \\
\text { member }\end{array}$ & $\begin{array}{l}\text { Member memilih } \\
\text { Menampilkan data } \\
\text { Profil member }\end{array}$ & $\begin{array}{l}\text { Menampilkan data Profil } \\
\text { member }\end{array}$ & Berhasil \\
\hline 7 & $\begin{array}{l}\text { Mengubah Profil } \\
\text { member }\end{array}$ & $\begin{array}{l}\text { Member memilih } \\
\text { mengubah data } \\
\text { Profil member }\end{array}$ & $\begin{array}{l}\text { Mengubah data Profil } \\
\text { member }\end{array}$ & Berhasil \\
\hline 8 & $\begin{array}{l}\text { Menampilkan status } \\
\text { transaksi }\end{array}$ & $\begin{array}{l}\text { Member melihat status } \\
\text { transaksi dengan } \\
\text { menggunakan no transaksi }\end{array}$ & $\begin{array}{l}\text { Menampilkan status } \\
\text { transaksi }\end{array}$ & Berhasil \\
\hline 9 & $\begin{array}{l}\text { Menampilkan data } \\
\text { pemesanan }\end{array}$ & $\begin{array}{l}\text { Member melihat } \\
\text { data pemesanan yang } \\
\text { dilakukan member }\end{array}$ & $\begin{array}{lr}\text { Menampilkan dataa } \\
\text { pemesanan yang } \\
\text { member lakukan }\end{array}$ & Berhasil \\
\hline 10 & $\begin{array}{l}\text { Menampilkan data } \\
\text { transaksi pembelian }\end{array}$ & $\begin{array}{l}\text { Member } \text { memilih } \\
\text { menu melihat }\end{array}$ & $\begin{array}{l}\text { Menampilkan data } \\
\text { pembelian yang telah }\end{array}$ & Berhasil \\
\hline 11 & $\begin{array}{l}\text { Menginputkan data } \\
\text { pemesanan }\end{array}$ & $\begin{array}{l}\text { Member memilih } \\
\text { produk-produk yang } \\
\text { ingin di pesan } \\
\text { dan menginputkan alamat } \\
\text { pengiriman }\end{array}$ & $\begin{array}{l}\text { Menyimpan data } \\
\text { pemesanan member dan } \\
\text { memproses total bayar yang } \\
\text { harus di bayarkan }\end{array}$ & Berhasil \\
\hline 12 & $\begin{array}{l}\text { Menginputkan data } \\
\text { konfirmasi } \\
\text { pembayaran }\end{array}$ & $\begin{array}{l}\text { Member melihat } \\
\text { data pemesanan dan } \\
\text { memilih konfirmasi } \\
\text { pembayaran kemudian } \\
\text { menginputkan data } \\
\text { bukti pembayaran }\end{array}$ & $\begin{array}{l}\text { Menyimpan data } \\
\text { bukti pembayaran dari } \\
\text { member }\end{array}$ & Berhasil \\
\hline 13 & $\begin{array}{l}\text { Menampilkan Profil } \\
\text { pelapak }\end{array}$ & $\begin{array}{l}\text { Pelapak memilih } \\
\text { menampilkan data } \\
\text { Profil member }\end{array}$ & $\begin{array}{l}\text { Menampilkan data } \\
\text { Profil pelapak }\end{array}$ & Berhasil \\
\hline 14 & $\begin{array}{l}\text { Mengubah } \quad \text { Profil } \\
\text { pelapak }\end{array}$ & $\begin{array}{l}\text { Pelapak memilih } \\
\text { mengubah data } \\
\text { Profil member }\end{array}$ & $\begin{array}{l}\text { Mengubah data Profil } \\
\text { pelapak }\end{array}$ & Berhasil \\
\hline 15 & $\begin{array}{l}\text { Menginputkan data } \\
\text { produk }\end{array}$ & $\begin{array}{l}\text { Pelapk memilih menu } \\
\text { produk baru dan kemudian } \\
\text { memsaukkan data produk } \\
\text { baru }\end{array}$ & $\begin{array}{l}\text { Menyimpan produk } \\
\text { baru yang di inputkan pelapak }\end{array}$ & Berhasil \\
\hline
\end{tabular}




\begin{tabular}{|c|c|c|c|c|}
\hline 16 & $\begin{array}{l}\text { Mengubah data } \\
\text { produk }\end{array}$ & $\begin{array}{l}\text { Pelapak memilih lihat } \\
\text { data produk dan memilih } \\
\text { salah satu produk yang } \\
\text { akan di ubah kemudian } \\
\text { mengubah data produk }\end{array}$ & $\begin{array}{l}\text { Menyimpan } \\
\text { perubahan data } \\
\text { produk yang di } \\
\text { ubah oleh pelapak }\end{array}$ & Berhasil \\
\hline 17 & $\begin{array}{l}\text { Menghapus data } \\
\text { produk }\end{array}$ & $\begin{array}{l}\text { Pelapak memilih } \\
\text { lihat data produk dan } \\
\text { memilih salah satu produk } \\
\text { yang akan di hapus }\end{array}$ & $\begin{array}{l}\text { Menghapus data } \\
\text { produk yang di } \\
\text { pelapak }\end{array}$ & Berhasil \\
\hline 18 & $\begin{array}{l}\text { Menampilkan } \\
\text { pemesanan member }\end{array}$ & $\begin{array}{l}\text { Pelapak memilih } \\
\text { menu pemesanan member } \\
\text { untuk melihat pemesanan } \\
\text { yang akan di proses }\end{array}$ & $\begin{array}{l}\text { Menampilkan data } \\
\text { pemesanan yang di lakukan } \\
\text { oleh member }\end{array}$ & Berhasil \\
\hline 19 & $\begin{array}{l}\text { Menampilkan } \\
\text { penyetoran }\end{array}$ & $\begin{array}{l}\text { Pelapak memilih } \\
\text { menu penyetoran member } \\
\text { untuk melihat penyetoran } \\
\text { dari agen }\end{array}$ & $\begin{array}{l}\text { Menampilkan data } \\
\text { penyetoran dari agen yang } \\
\text { transaksinya sudah selesai. }\end{array}$ & Berhasil \\
\hline 20 & $\begin{array}{l}\text { Menampilkan } \\
\text { transaksi penjualan }\end{array}$ & $\begin{array}{l}\text { Pelapak memilih } \\
\text { menu melihat data } \\
\text { transaksi penjualan }\end{array}$ & $\begin{array}{lcc}\text { Menampilkan data } & \\
\text { penjualan } & \text { yang } \\
\text { dilakukan oleh pelapak } & \text { telah }\end{array}$ & Berhasil \\
\hline 21 & $\begin{array}{l}\text { Menginputkan } \\
\text { konfirmasi } \\
\text { pengiriman }\end{array}$ & $\begin{array}{l}\text { Pelapak melihat } \\
\text { pemesanan dan memilih } \\
\text { pemesanan untuk } \\
\text { menginputkan bukti } \\
\text { konfirmasi pengiriman }\end{array}$ & $\begin{array}{l}\text { Menginputkan data } \\
\text { bukti pengiriman } \\
\text { pemesanan . }\end{array}$ & Berhasil \\
\hline 22 & $\begin{array}{l}\text { Menampilkan } \\
\text { notifikasi transaksi }\end{array}$ & $\begin{array}{l}\text { Agen memilih } \\
\text { menu melihat } \\
\text { notifikasi transaksi }\end{array}$ & $\begin{array}{l}\text { Menampilkan } \\
\text { transaksi dari transaksi yang di } \\
\text { ajukan ke status transaksi } \\
\text { selanjutnya }\end{array}$ & Berhasil \\
\hline 23 & $\begin{array}{l}\text { Menghapus notifikasi } \\
\text { transaksi }\end{array}$ & $\begin{array}{l}\text { Agen memilih } \\
\text { menu melihat } \\
\text { notifikasi transaksi } \\
\text { dan memilih notifikasi } \\
\text { yang akan di hapus }\end{array}$ & $\begin{array}{l}\text { Menghapus notifikasi } \\
\text { transaksi }\end{array}$ & Berhasil \\
\hline 24 & $\begin{array}{l}\text { Mengubah status } \\
\text { transaksi }\end{array}$ & $\begin{array}{l}\text { Agen memilih } \\
\text { menu melihat } \\
\text { notifikasi transaksi } \\
\text { dan memilih notifikasi } \\
\text { yang akan di ubah } \\
\text { status transaksi }\end{array}$ & $\begin{array}{l}\text { Mengubah } \\
\text { transaksi }\end{array}$ & Berhasil \\
\hline 25 & $\begin{array}{l}\text { Menampilkan } \\
\text { konfirmasi } \\
\text { pengiriman }\end{array}$ & $\begin{array}{l}\text { Agen memilih } \\
\text { menu melihat } \\
\text { konfirmasi } \\
\text { pengiriman }\end{array}$ & $\begin{array}{l}\text { Menampilkan } \\
\text { konfirmasi pengiriman }\end{array}$ & Berhasil \\
\hline
\end{tabular}




\begin{tabular}{|c|c|c|c|c|}
\hline 26 & $\begin{array}{l}\text { Menampilkan } \\
\text { konfirmasi } \\
\text { pembayaran }\end{array}$ & $\begin{array}{l}\text { Agen memilih } \\
\text { menu melihat } \\
\text { konfirmasi pembayaran }\end{array}$ & $\begin{array}{l}\text { Menampilkan } \\
\text { konfirmasi pembayaran }\end{array}$ & Berhasil \\
\hline 27 & $\begin{array}{l}\text { Menghapus } \\
\text { konfirmasi } \\
\text { pengiriman }\end{array}$ & $\begin{array}{l}\text { Agen memilih } \\
\text { menu melihat } \\
\text { konfirmasi pengiriman } \\
\text { dan memilih konfirmasi } \\
\text { pengiriman yang akan di } \\
\text { hapus }\end{array}$ & $\begin{array}{l}\text { Menghapus } \\
\text { konfirmasi pengiriman }\end{array}$ & Berhasil \\
\hline 28 & $\begin{array}{l}\text { Menghapus } \\
\text { konfirmasi } \\
\text { pembayaran }\end{array}$ & $\begin{array}{l}\text { Agen memilih } \\
\text { menu melihat } \\
\text { konfirmasi pembayaran } \\
\text { dan memilih konfirmasi } \\
\text { pembayaran } \\
\text { yang akan di hapus }\end{array}$ & $\begin{array}{l}\text { Menghapus } \\
\text { konfirmasi pembayaran }\end{array}$ & Berhasil \\
\hline 29 & $\begin{array}{l}\text { Menginputkan data } \\
\text { kategori produk }\end{array}$ & $\begin{array}{l}\text { Pelapk memilih } \\
\text { menu kategori produk } \\
\text { dan kemudian } \\
\text { memasukkan } \\
\text { data produk baru }\end{array}$ & $\begin{array}{l}\text { Menyimpan kategori } \\
\text { produk yang di inputkan } \\
\text { agen }\end{array}$ & Berhasil \\
\hline 30 & $\begin{array}{l}\text { Menampilkan data } \\
\text { kategori produk }\end{array}$ & $\begin{array}{l}\text { Agen memilih } \\
\text { menu melihat } \\
\text { kategori produk }\end{array}$ & $\begin{array}{l}\text { Agen memilih menu } \\
\text { melihat kategori produk }\end{array}$ & Berhasil \\
\hline 31 & $\begin{array}{l}\text { Mengubah data } \\
\text { kategori produk }\end{array}$ & $\begin{array}{l}\text { Pelapak memilih } \\
\text { lihat data kategori produk } \\
\text { dan memilih salah satu } \\
\text { kategori produk yang } \\
\text { akan di ubah kemudian } \\
\text { mengubah data kategori } \\
\text { produk }\end{array}$ & $\begin{array}{l}\text { Menyimpan } \\
\text { perubahan data kategori produk } \\
\text { yang di ubah oleh agen }\end{array}$ & Berhasil \\
\hline 32 & $\begin{array}{l}\text { Menghapus kategori } \\
\text { produk }\end{array}$ & $\begin{array}{l}\text { Pelapak memilih } \\
\text { lihat data kategori produk } \\
\text { dan memilih } \\
\text { salah satu } \\
\text { kategori produk yang } \\
\text { akan di hapus }\end{array}$ & $\begin{array}{l}\text { Menghapus data } \\
\text { kategori produk yang di pilih } \\
\text { oleh agen }\end{array}$ & Berhasil \\
\hline 33 & $\begin{array}{l}\text { Menginputkan } \\
\text { penyetoran }\end{array}$ & $\begin{array}{l}\text { Agen memilih } \\
\text { menu penyetoran dan } \\
\text { memilih pelapak } \\
\text { kemudian } \\
\text { menginputkan data } \\
\text { penyetoran }\end{array}$ & $\begin{array}{l}\text { Menyimpan data } \\
\text { penyetoran }\end{array}$ & Berhasil \\
\hline 34 & $\begin{array}{l}\text { Menampilkan data } \\
\text { member }\end{array}$ & $\begin{array}{lr}\text { Agen } & \text { memilih } \\
\text { menu } & \text { melihat } \\
\text { member } & \end{array}$ & $\begin{array}{l}\text { Menampilkan semua } \\
\text { member }\end{array}$ & Berhasil \\
\hline
\end{tabular}




\begin{tabular}{|c|c|c|c|c|}
\hline 35 & $\begin{array}{l}\text { Menampilkan data } \\
\text { pelapak }\end{array}$ & $\begin{array}{ll}\text { Agen } & \text { memilih } \\
\text { menu } & \text { melihat pelapak }\end{array}$ & $\begin{array}{l}\text { Menampilkan semua } \\
\text { pelapak }\end{array}$ & Berhasil \\
\hline 36 & Menghapus member & $\begin{array}{l}\text { Agen memilih } \\
\text { menu melihat member dan } \\
\text { memilih member yang } \\
\text { akan di hapus }\end{array}$ & Menghapus member & Berhasil \\
\hline 37 & Menghapus pelapak & $\begin{array}{l}\text { Agen memilih } \\
\text { menu melihat pelapak dan } \\
\text { memilih pelapak yang } \\
\text { akan di hapus }\end{array}$ & Menghapus pelapak & Berhasil \\
\hline 38 & $\begin{array}{l}\text { Menampilkan } \\
\text { potongan penyetoran }\end{array}$ & $\begin{array}{l}\text { Agen memilih } \\
\text { menampilkan } \\
\text { potongan penyetoran }\end{array}$ & $\begin{array}{l}\text { Menampilkan } \\
\text { potongan penyetoran }\end{array}$ & Berhasil \\
\hline 39 & $\begin{array}{l}\text { Mengubah data } \\
\text { potongan penyetoran }\end{array}$ & $\begin{array}{l}\text { Pelapak memilih } \\
\text { lihat data } \\
\text { potongan penyetoran } \\
\text { dan memilih salah } \\
\text { satu potongan } \\
\text { penyetoran yang akan } \\
\text { di ubah kemudian } \\
\text { mengubah data } \\
\text { potongan penyetoran }\end{array}$ & $\begin{array}{l}\text { Menyimpan } \\
\text { perubahan data potongan } \\
\text { penyetoran yang di ubah oleh } \\
\text { agen }\end{array}$ & Berhasil \\
\hline 40 & $\begin{array}{l}\text { Menampilkan data } \\
\text { transaksi }\end{array}$ & $\begin{array}{l}\text { Agen memilih } \\
\text { menampilkan data } \\
\text { transaksi }\end{array}$ & $\begin{array}{l}\text { Menampilkan data } \\
\text { transaksi }\end{array}$ & Berhasil \\
\hline 41 & Menghapus transaksi & $\begin{array}{l}\text { Agen memilih } \\
\text { menu melihat transaksi } \\
\text { dan memilih } \\
\text { transaksi yang akan di } \\
\text { hapus }\end{array}$ & Menghapus transaksi & Berhasil \\
\hline 42 & $\begin{array}{l}\text { Menginputkan data } \\
\text { agen }\end{array}$ & $\begin{array}{l}\text { Agen memilih } \\
\text { menu agen dan } \\
\text { menginputkan data agen }\end{array}$ & Menyimpan data agen & Berhasil \\
\hline 43 & $\begin{array}{l}\text { Menampilkan data } \\
\text { agen }\end{array}$ & $\begin{array}{l}\text { Agen memilih } \\
\text { menampilkan data } \\
\text { agen }\end{array}$ & $\begin{array}{l}\text { Menampilkan data } \\
\text { agen }\end{array}$ & Berhasil \\
\hline 44 & Mengubah data agen & $\begin{array}{l}\text { Pelapak memilih } \\
\text { lihat data agen dan } \\
\text { memilih salah satu agen } \\
\text { yang akan di ubah } \\
\text { kemudian mengubah data } \\
\text { agen }\end{array}$ & $\begin{array}{l}\text { Menyimpan } \\
\text { perubahan data agens yang di } \\
\text { ubah oleh agen }\end{array}$ & Berhasil \\
\hline
\end{tabular}


Indonesian Journal of Applied Informatics, Vol.1 No. 1 November 2016

ISSN: 2548-3846

\begin{tabular}{|c|c|c|c|c|}
\hline 45 & Menghapus agen & $\begin{array}{l}\text { Agen memilih } \\
\text { menu melihat agen dan } \\
\text { memilih agen yang akan } \\
\text { di hapus }\end{array}$ & Menghapus agen & Berhasil \\
\hline 46 & $\begin{array}{l}\text { Menampilkan } \\
\text { Tentang Marketplace }\end{array}$ & $\begin{array}{l}\text { Pengunjung } \\
\text { memilih } \\
\text { menampilkan } \\
\text { Tentang Marketplace }\end{array}$ & $\begin{array}{l}\text { Menampilkan } \\
\text { Tentang Marketplace }\end{array}$ & Berhasil \\
\hline 47 & $\begin{array}{l}\text { Menampilkan Aturan } \\
\text { Penggunaan }\end{array}$ & $\begin{array}{l}\text { Pengunjung } \\
\text { memilih } \\
\text { menampilkan Aturan } \\
\text { Penggunaan }\end{array}$ & $\begin{array}{l}\text { Menampilkan Aturan } \\
\text { Penggunaan }\end{array}$ & Berhasil \\
\hline 48 & $\begin{array}{l}\text { Menampilkan } \\
\text { Pengumuman }\end{array}$ & $\begin{array}{l}\text { Pengunjung } \\
\text { memilih } \\
\text { menampilkan } \\
\text { Pengumuman }\end{array}$ & $\begin{array}{l}\text { Menampilkan } \\
\text { Pengumuman }\end{array}$ & Berhasil \\
\hline 49 & $\begin{array}{l}\text { Menampilkan cara } \\
\text { menjadi member }\end{array}$ & $\begin{array}{l}\text { Pengunjung } \\
\text { memilih } \\
\text { menampilkan } \\
\text { cara menjadi member }\end{array}$ & $\begin{array}{l}\text { Menampilkan cara } \\
\text { menjadi member }\end{array}$ & Berhasil \\
\hline 50 & $\begin{array}{l}\text { Menampilkan cara } \\
\text { belanja }\end{array}$ & $\begin{array}{l}\text { Pengunjung } \\
\text { memilih menampilkan } \\
\text { cara belanja }\end{array}$ & $\begin{array}{l}\text { Menampilkan cara } \\
\text { belanja }\end{array}$ & Berhasil \\
\hline 51 & $\begin{array}{l}\text { Menampilkan cara } \\
\text { pembayaran }\end{array}$ & $\begin{array}{l}\text { Pengunjung } \\
\text { memilih menampilkan } \\
\text { cara pembayaran }\end{array}$ & $\begin{array}{l}\text { Menampilkan cara } \\
\text { pembayaran }\end{array}$ & Berhasil \\
\hline 52 & $\begin{array}{l}\text { Menampilkan } \\
\text { peraturan menjadi } \\
\text { member }\end{array}$ & $\begin{array}{l}\text { Pengunjung } \\
\text { memilih menampilkan } \\
\text { peraturan menjadi } \\
\text { member }\end{array}$ & $\begin{array}{l}\text { Menampilkan } \\
\text { peraturan menjadi } \\
\text { member }\end{array}$ & Berhasil \\
\hline 53 & $\begin{array}{l}\text { Menampilkan cara } \\
\text { menjadi pelapak }\end{array}$ & $\begin{array}{l}\text { Pengunjung } \\
\text { memilih menampilkan } \\
\text { cara menjadi pelapak }\end{array}$ & $\begin{array}{l}\text { Menampilkan cara } \\
\text { menjadi pelapak }\end{array}$ & Berhasil \\
\hline
\end{tabular}




\begin{tabular}{|c|l|l|l|l|}
\hline 54 & $\begin{array}{l}\text { Menampilkan cara } \\
\text { berjualan }\end{array}$ & $\begin{array}{l}\text { Pengunjung } \\
\text { memilih } \\
\text { menampilkan cara } \\
\text { berjualan }\end{array}$ & $\begin{array}{l}\text { Menampilkan cara } \\
\text { berjualan }\end{array}$ & Berhasil \\
\hline 55 & $\begin{array}{l}\text { Menampilkan } \\
\text { peraturan menjadi } \\
\text { pelapak }\end{array}$ & $\begin{array}{l}\text { Pengunjung } \\
\text { memilih } \\
\text { menampilkan } \\
\text { bantuan }\end{array}$ & $\begin{array}{l}\text { Menampilkan } \\
\text { peraturan menjadi pelapak }\end{array}$ & Berhasil \\
\hline 56 & $\begin{array}{l}\text { Menampilkan data } \\
\text { slide }\end{array}$ & $\begin{array}{l}\text { Pelapak memilih } \\
\text { menampilkan data } \\
\text { slide }\end{array}$ & $\begin{array}{l}\text { Menampilkan data } \\
\text { slide dari pelapak }\end{array}$ & Berhasil \\
\hline 57 & $\begin{array}{l}\text { Mengubah data slide } \\
\text { data slide dan mengubah } \\
\text { data slide }\end{array}$ & $\begin{array}{l}\text { Mengubah data slide } \\
\text { dari pelapak }\end{array}$ & Berhasil \\
\hline 50 & $\begin{array}{l}\text { Menginputkan } \\
\text { produk yang di } \\
\text { tampilkan di slider }\end{array}$ & $\begin{array}{l}\text { Pelapak memilih } \\
\text { menu input slide dan } \\
\text { menginputkan data slide }\end{array}$ & $\begin{array}{l}\text { Menyimpan data slide } \\
\text { dari pelapak }\end{array}$ & Berhasil \\
\hline 59 & $\begin{array}{l}\text { Mencetak laporan } \\
\text { penyetoran }\end{array}$ & $\begin{array}{l}\text { Agen memilih } \\
\text { menu cetak laporan } \\
\text { penyetoran dan } \\
\text { memasukkan } \\
\text { tanggal }\end{array}$ & $\begin{array}{l}\text { Mencetak laporan } \\
\text { sesuai tanggal yang di inputkan } \\
\text { baru }\end{array}$ & Berhasil \\
\hline
\end{tabular}

\section{KESIMPULAN}

E-Market Place Batik memberikan fasilitas penghubung antara penjual batik dan pembeli batik. Desain program menggunakan Use Case dan Class Diagram berdasarkan analisis kebutuhan sistem dengan menggunakan kebutuhan fungsional. Program telah diuji dengan menggunakan metode Black-box yang daftar pengujiannya berdasarkan kebutuhan fungsional dan hasilnya semua fungsi dapat berjalan dengan baik. 


\section{DAFTAR PUSTAKA}

[1] C. B. and S. M. , "Internet marketing and export market growth in Chile," ELSEVIER, vol. 69, no. Journal of Business Research, pp. 426-434, 2016.

[2] Y. Kwon and S. Cho, "Defining a cluster market: The case of the Korean Internet," ELSEVIER, vol. 39, no. Telecommunications Policy, pp. 921-932, 2015.

[3] S. Mathews, C. Bianchi, K. J. Perks, M. Healy and R. Wickramasekera, "Internet marketing capabilities and international market growth," ELSIVIER, vol. 25, no. International Business Review, pp. 820-830, 2016.

[4] P. Liang and S. Guo, "Social interaction, Internet access and stock market --An empirical study in China," ELSIVIER, vol. 43, no. Journal of Comparatie Economics, pp. 883-901, 2015.

[5] M. Fowler, A Brief Guide to the Standart Object Modeling Language, Boston: Pearson Education, 2004.

[6] K. D. Norma, "Batik Center Solo dengan Penakanan Desain," Canopy, vol. 3, no. Journal of Architectur, pp. 8-15, 2014.

[7] R. S. Pressman, Software Engineering, San Francisco: Mc Graw Hill, 2010. 